\title{
In-situ investigations on small- scale local and short- term changes of sublittoral macrobenthos in Lübeck Bay (western Baltic Sea)
}

\author{
U. Rogal ${ }^{1}$, K. Anger ${ }^{2}$, G. SChriever ${ }^{1} \&$ C. VAlentin $^{1}$ \\ 1Zoologisches Institut, Universität Kiel; \\ Hegewischstr. 3, D-2300 Kiel, \\ and \\ 2Biologische Anstalt Helgoland (Meeresstation); \\ D-2192 Helgoland, Federal Republic of Germany
}

\begin{abstract}
In-situ studies on sublittoral soft bottom macrofauna (depth: 14-16 m) employing the underwater laboratory (UWL) "Helgoland" were carried out. Sets of samples were compared for small-scale local and short-term changes in species richness, faunal abundance, numerical dominance, diversity, evenness, homogeneity, and similarity. It could be shown that minor differences in sediment quality can cause conspicuous heterogeneity within a small sampling area (diameter: ca. $100 \mathrm{~m}$ ). Both spatfall and mortality of benthic invertebrates can change the faunal structure within a short period (two months). The degree of change varies between species and thus at stations harbouring different faunal assemblages as well.
\end{abstract}

\section{INTRODUCTION}

The soft-bottom macrofauna of the western Baltic Sea is largely known from sampling carried out by means of grabs operated from aboard ships (KühlmorgenHille, 1963, 1965; Schulz, 1969 a, b; Arntz, 1971; Arntz \& Brunswig, 1975; Rogal, 1977). These authors were concerned with large scale zonations, production, and the relationship between water depth, sediment quality and macrofauna composition. This study concentrates on estimating homogeneity structures and on the extent of smallscale local and short-term changes. Suitable precision using a research vessel would not have been possible because of potential navigation problems (Dekka inaccuracy), drifting of the ship, movement around the anchor, and the difficulty in obtaining quantitative samples with a grab (for more detailed discussion of these problems and further literature see Rogal, 1977, and Dittmer, 1977).

Saturation diving missions during June 17-30 and August 13-30, 1976, utilizing the underwater laboratory (UWL "Helgoland"), offered the best conditions for taking on the task in an appropriate way. The UWL was anchored at a depth of $15 \mathrm{~m}$ off Pelzerhaken $\left(54^{\circ} 05.8^{\prime} \mathrm{N} / 10^{\circ} 55.2^{\prime} \mathrm{E}\right)$ in Lübeck Bay. 


\section{MATERIALS AND METHODS}

Three sampling stations were fixed at the ends of the NW $\left(315^{\circ}\right), \mathrm{SE}\left(135^{\circ}\right)$ and SW $\left(225^{\circ}\right)$ orientation lines and numbered 1 to 3 . Their distance from the UWL was about $70 \mathrm{~m}$. Moreover, drifting algal carpets ("phytal") were studied as a possible reservoir for immigrating (and possibly emigrating) benthic organisms. This phytal biotope was not locally fixed. A general description of the investigation area and a survey of the algal species found there is given by Anger et al. (1977).

On June 27/28 fifteen parallel samples were taken only at Stations 1 and 2. On August 15, ten further samples were taken at all three stations and in the phytal biotope. Thus, our study is based upon 70 quantitative samples, which were obtained by means of sediment corers with a diameter of $9 \mathrm{~cm}\left(=63.6 \mathrm{~cm}^{2}\right)$ and a height of $10 \mathrm{~cm}$, their upper side being covered by nylon gauze (mesh size: $0.5 \mathrm{~mm}$ ). The parallel samples were taken randomly at each station to satisfy statistical requirements. They were sieved within the UWL through a screen with the same mesh size, sorted under sterco microscopes, and the fauna identified and partly measured with an eyepiece micrometer. Parallel sediment samples of all three stations were analysed at the Geological Institute of Kiel University using a wet sedimentation technique.

The following parameters were estimated for an ecological structure analysis: (1) Species number (S), (2) abundance $\left(\mathrm{n} \cdot \mathrm{m}^{-2}\right)$, (3) numerical dominance (D), (4) diversity ( $\mathrm{H}^{\prime}$ as Shannon-Weaver function) and maximum diversity ( $\left.\mathrm{H}^{\prime} \max \right),(5)$ evenness (I') (for the last two items see Pielou, 1966 a, b, 1969), (6) Czekanowski-Index (C) as sum of the smaller dominance-percentages of all species common for both samples being compared, also known as index of affinity (Sanders, 1960) (measure of quantitative similarity of two samples), (7) Jaccard-Index (J) as percentage of species shared by two samples (c.f. Jaccard, 1908, 1912; Whittaker, 1967) and measure of qualitative similarity of two samples.

After testing the distribution of the data and appropriate transformations, the following commonly used significance tests were used: $F$ - test, $t$ - test, analysis of variance with Bartlett - test, and range tests after Duncan and Tukey.

\section{RESULT'S AND DISCUSSION}

The sediment characteristics of all three stations are summarized in Table 1. It reveals that the whole investigation area was predominantly covered by fine sand, and the deepest station (2) had the highest silt content (for classification used here see Kolp 1966). There, the samples showed a higher variation than at the other stations, suggesting an increased heterogeneity within a small area. Stations 1 and 3 contained greater median grain sizes, with the sediment being coarsest at Station 1. This observation is related to water depth.

Table 2 gives a survey of the macrofauna. Qualitative suction samples demonstrated the occurrence of the polychaetes Eumida sanguinea and Laonome kröyeri, the opisthobranch Facelina spec., and the decapods Carcinus maenas and Crangon cran- 
Table 1

Characteristics of sediment quality

\begin{tabular}{|cccccc|}
\hline Station & Sample & $\begin{array}{c}\text { Median value } \\
(\mu \mathrm{m})\end{array}$ & $\begin{array}{c}\text { Fraction } \\
630-200 \mu \mathrm{m} \\
(\%)\end{array}$ & $\begin{array}{c}\text { Fraction } \\
200-63 \mu \mathrm{m} \\
(\mathbf{0} \%)\end{array}$ & $\begin{array}{c}\text { Fraction } \\
<63 \mu \mathrm{m} \\
(\%)\end{array}$ \\
\hline \multirow{2}{*}{1} & A & 127 & 11.5 & 87.6 & 0.8 \\
& B & 128 & 9.4 & 88.9 & 1.5 \\
& C & 129 & 10.8 & 87.6 & 1.4 \\
\hline \multirow{2}{*}{2} & A & 90 & 3.2 & 78.5 & 12.5 \\
& B & 97 & 16.5 & 74.2 & 8.0 \\
& C & 95 & 1.0 & 87.4 & 8.5 \\
\hline \multirow{2}{*}{3} & A & 102 & 2.4 & 92.5 & 4.9 \\
& B & 107 & 3.3 & 89.8 & 5.2 \\
& C & 100 & 1.3 & 93.5 & 5.0 \\
\hline
\end{tabular}

gon. Adult individuals of the clam Cyprina islandica and the lug worm, Arenicola marina, were also found frequently.

\section{Homogeneity}

Parallel samples never correspond exactly in terms of species composition and dominance of all single species, even if taken from the immediate neighbourhood. The degree of correspondence is a characteristic value for a station. It is called "homogeneity", and can be measured by the index of Czekanowski (see above). The mean dominance similarity value, which in this case is a precondition for statistic tests, is obtained by multiple comparison of groups of parallel samples.

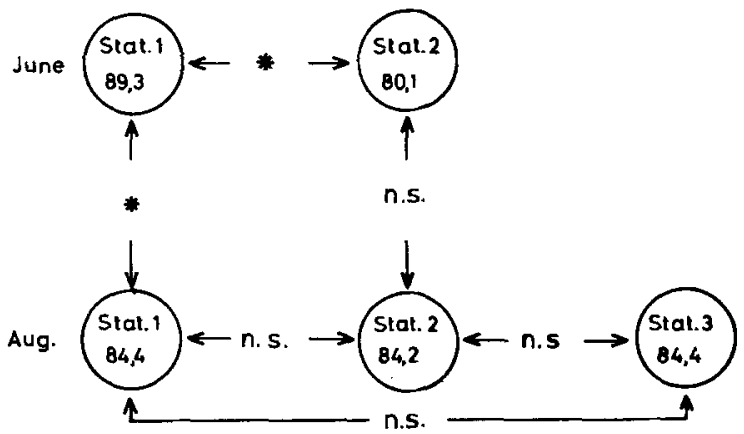

Fig. 1: Percentage homogeneity, measured as index of Czekanowski. Statistically significant differences marked with asterisks

The results of this homogeneity comparison are given in Figure 1. The homogeneity values are high (about $85 \%$ ) and mostly not significantly different from one station to another. 


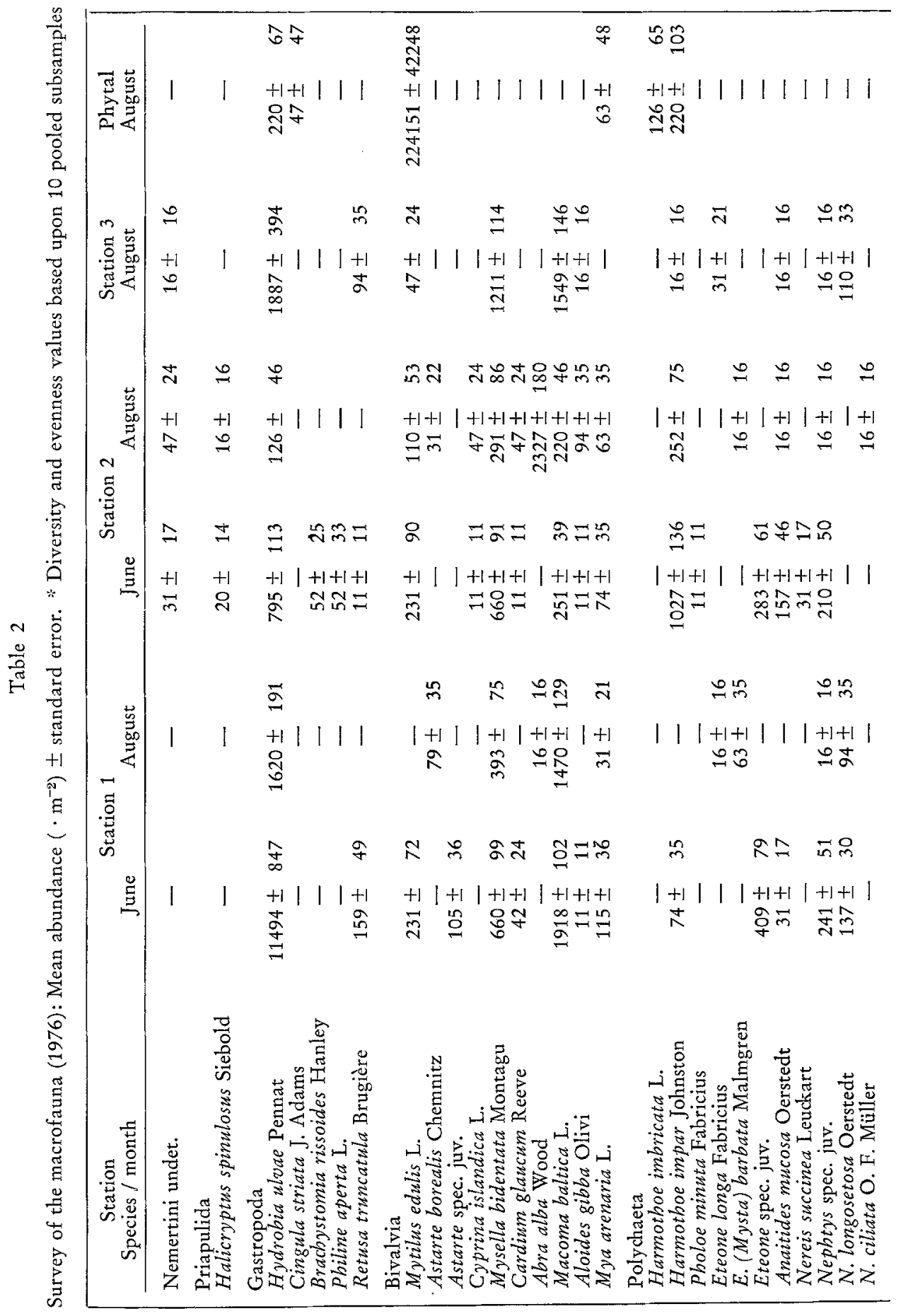




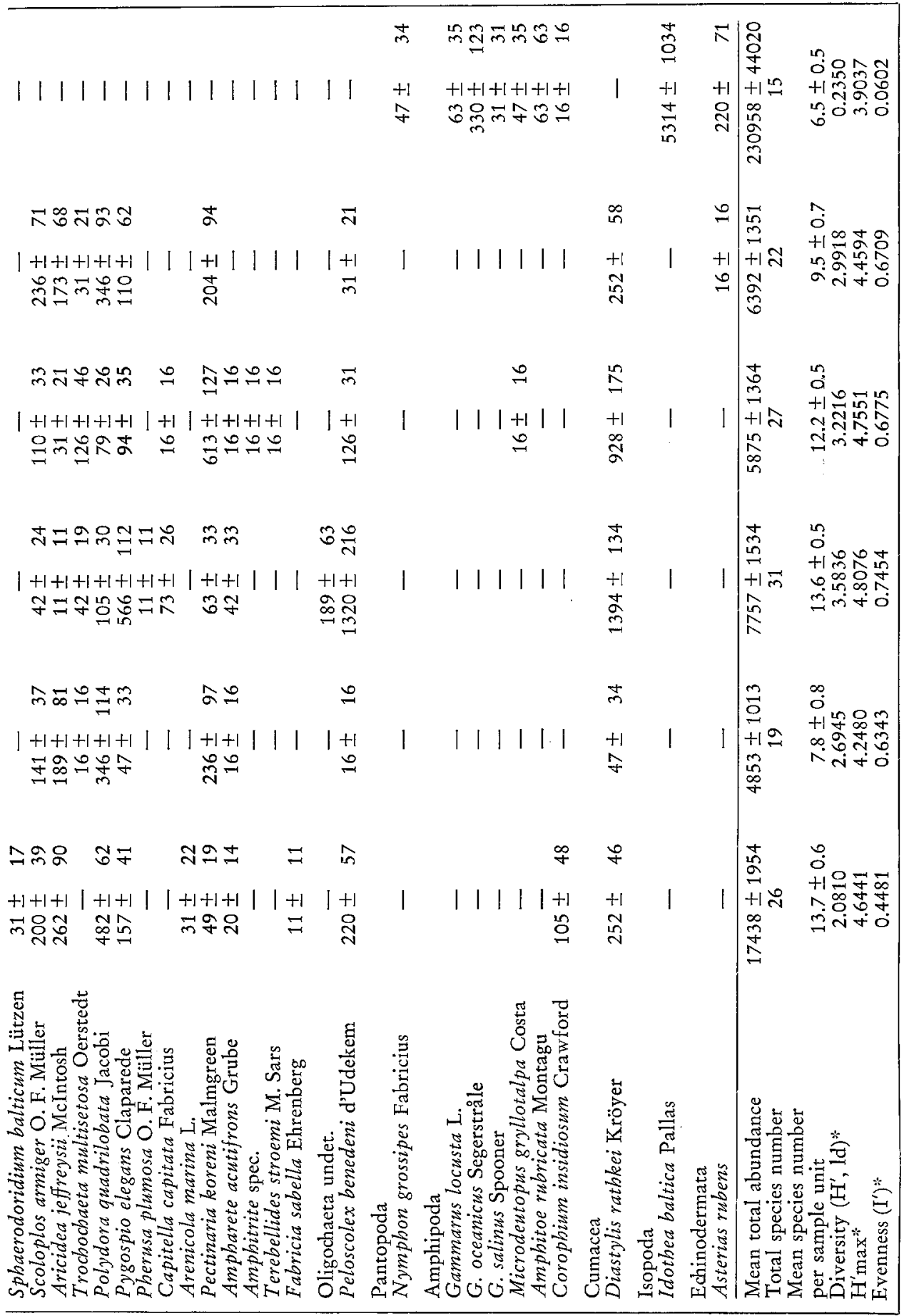



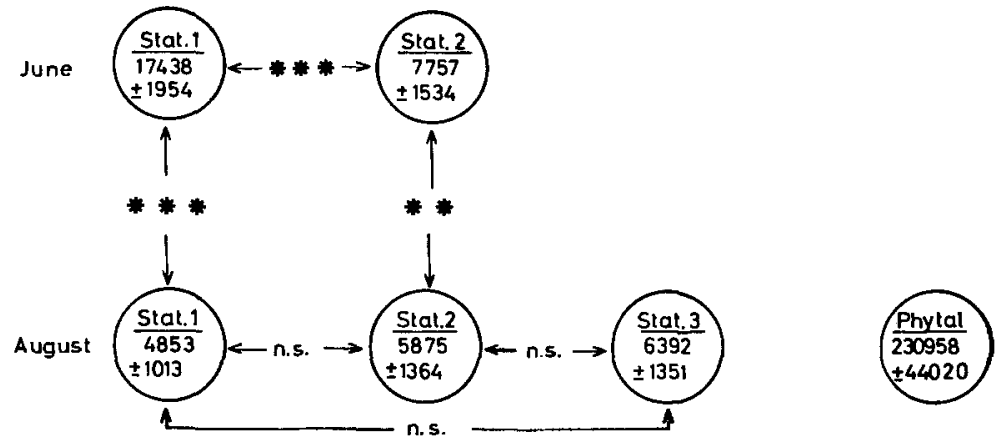

Fig. 2: Mean total macrofauna abundance $\left(\mathrm{n} \cdot \mathrm{m}^{-2}\right) \pm$ standard error. Statistically significant differences marked with asterisks (phytal biotope has significantly higher abundance than all sediment stations)

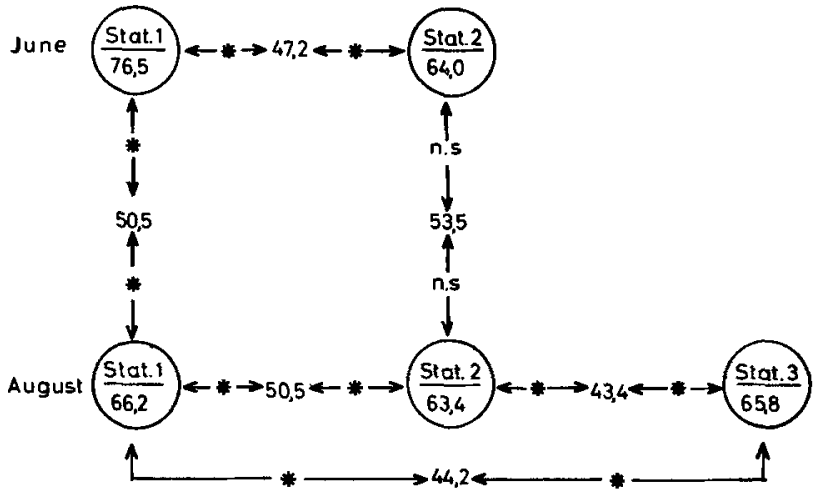

Fig. 3: Mean qualitative (Jaccard-) similarity $(\% / \%)$ between stations and between sampling dares. "Between - similarity" statistically tested against "within - similarities". Significantly lower "between - similarity" marked with asterisks

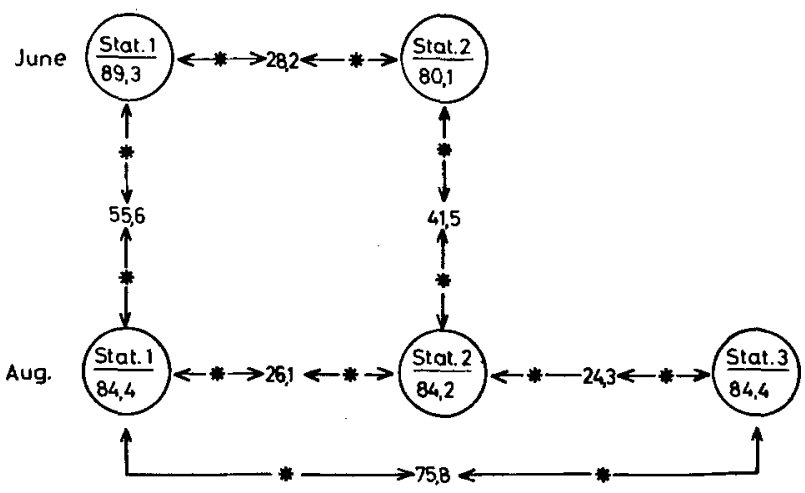

Fig. 4: Mean quantitative dominance (Czekanowski-) similarity ( $\%$ ) between stations and between sampling dates. For further explanation see Figure 3 
Sublittoral macrobenthos

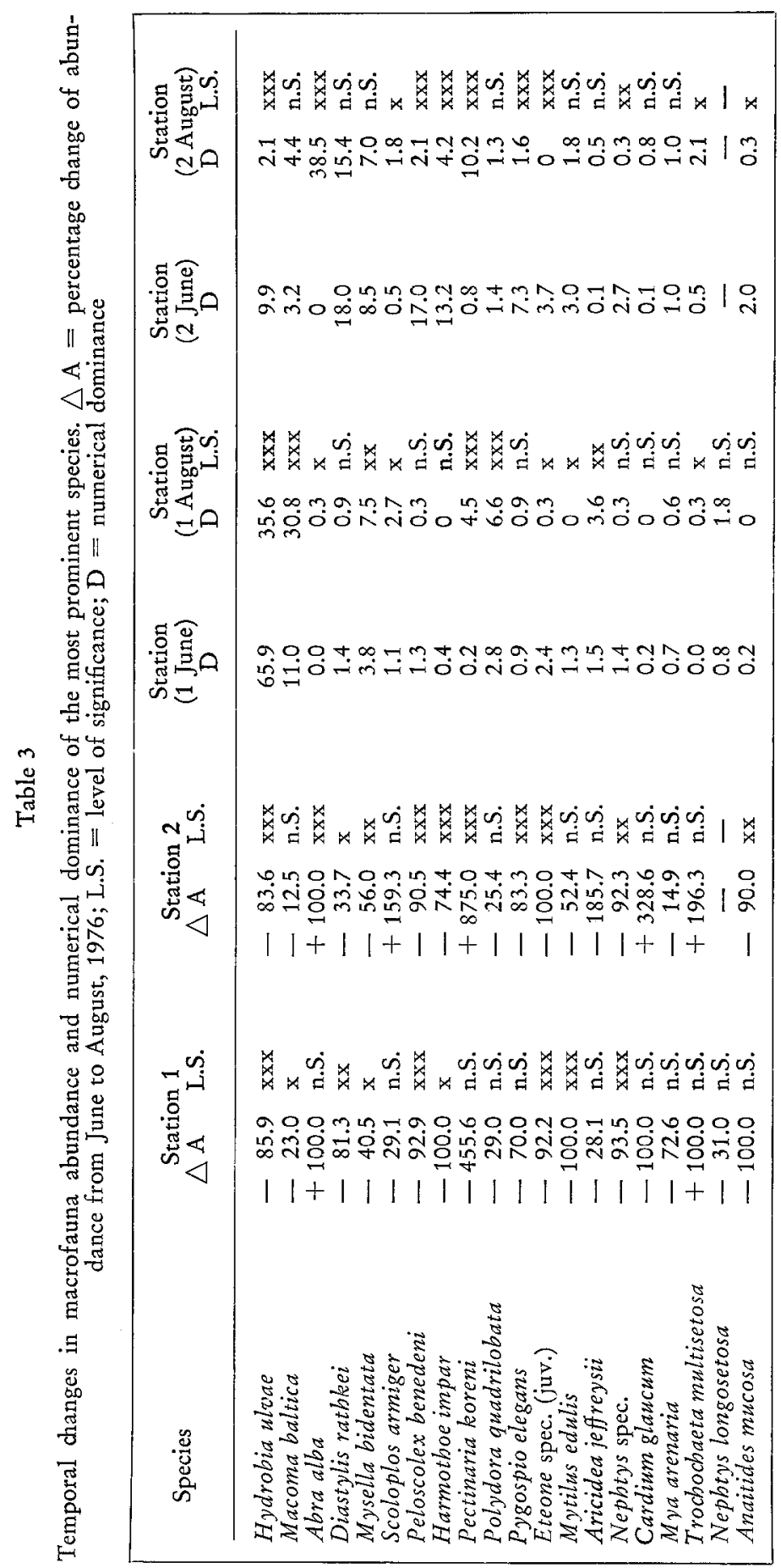




\section{Spatial differences}

Differences among the stations are presented in Figure 2 and in Tables 2 and 3: In June the total abundance at Station 1 is twice as high as at Station 2. In August all density values are lower than in June, and no significant differences among the stations can be observed. This assimilation process is caused by high mortality rates of young Hydrobia (decrease ca. $85 \%$ at both stations) and spatfall of Abra alba and Pectinaria koreni. The species number is significantly higher at Station 2 than at the other sampling sites in August.

All these spatial differences are also indicated by the indices of Jaccard and Czekanowski, if used as similarity measures for faunal assemblages. The former one considers only the qualitative component, the latter one also includes the relative densities of the single species. Both indices reveal significant spatial differences (Figs 3 and 4).

Figure 3 indicated only low qualitative similarity (average ca. $46 \%$ ) and Figure 4 even lower correspondence of mean dominance similarities. Stations 1 and 3, although significantly different in August, show the highest degree of similarity. This fact is assumed to be related to the lower silt content (average $3,1 \%$ ) as compared with that of station $2(9.7 \%)$. It can be concluded that even within a small area inconspicuous sediment changes can influence the faunal composition significantly.

The macrofauna of the mobile phytal biotope has hardly any similarity with that of the sediments. The extreme dominance of young mussels (Mytilus edulis) depresses the quantitative correspondence (C) to $1.7 \%$. The similarity of species composition $(\mathrm{J})$ is also very low $(8.6 \%)$. These algal carpets introduce great amounts of organic matter into the benthic subsystem and support growth and immigration of an important predator, Asterias rubens (Anger et al., 1977).

\section{Temporal changes}

Changes which occurred during the period June to August were only studied at Stations 1 and 2 (Fig. 2, Tables 2 and 3). A decrease in abundance is statistically highly significant for the total fauna (Fig. 2) and for many of the species (Table 3). The fact has to be interpreted according to the high initial mortality following settlement of meroplanktonic larvae or young bottom stages in May and June. This certainly holds true for Hydrobia ulvae (c.f. Fish \& Fish, 1974), Harmothoe impar, Eteone spec., Nephtys spec., Pygospio elegans, and Peloscolex benedeni. The density decline of Polydora quadrilobata is not significant. No juveniles of this spionid species were found, since it reproduces much later in the year (Hempel, 1957; Blake, 1969).

The mortality of the molluscs Hydrobia ulvae, Mysella bidentata, and Macoma baltica can at least partly be attributed to predation by demersal fishes and the sea star, Asterias rubens (Anger et al., 1977).

For Macoma baltica at Station 1 a size-frequency distribution was determined for both months (Fig. 5). According to this, the smallest clams had grown about $1 \mathrm{~mm}$ (ca. $40 \%$ ) within $6-7$ weeks, the larger ones about $2 \mathrm{~mm}(20 \%)$ in the same period. 
The first group is probably one, the second two years old (c.f. Segerstrale, 1960). The growth is greatest during this period of highest water temperatures (see also Gilbert, 1973; Green, 1973; Berg, 1974; Wilde, 1974; Warwick \& Price, 1975).

Diastylis ratbkei is the most important food item of demcrsal fishes in the western Baltic Sea (Arntz, 1971, 1974) and also a frequent prey of the sea star (Anger et al., 1977). However, since it carries out nocturnal vertical migrations related to moulting (Anger \& Valentin, 1976; Valentin \& Anger, 1977), possible drifting and exchange of populations make it hard to interpret temporal density changes at a fixed station.

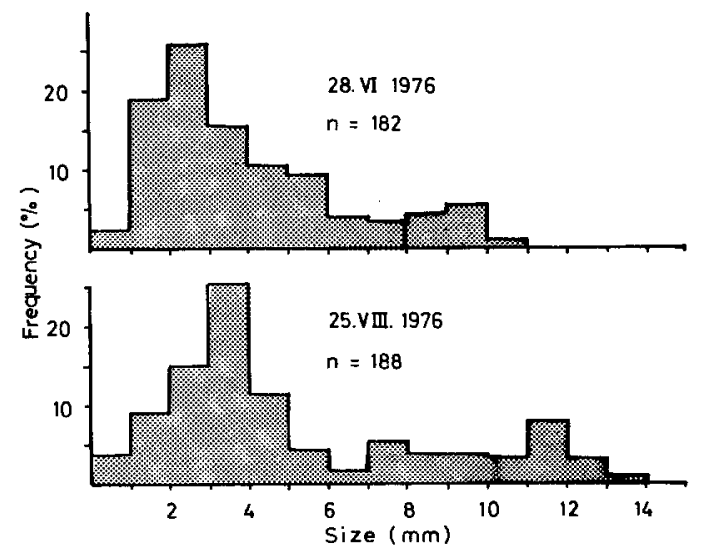

Fig. 5: Macoma baltica: Size - frequency distribution in June and August, 1976

Abra alba and Pectinaria koreni spawn somewhat later than the species discussed above (Rasmussen, 1973). They show a conspicuous increase in population density. In the former species the well known substrate preferrence is particularly obvious at Station 2: there its abundance is higher by a factor of 145 compared with Station 1 (Table 2). Like spatial differences, all temporal changes are also reflected by the indices of Jaccard and Czekanowski. Both numbers indicate significant alterations of the assemblage structures (Figs. 3 and 4). At Station 2, they cannot be revealed by species dissimilarity, but clearly by a low dominance similarity. The values for maximum diversity $\left(\mathrm{H}^{\prime} \max \right)$ in Table 2 show that rather considerable decreases in species numbers do not affect diversity severely. Thus, fluctuations in $\mathrm{H}^{\prime}$ are caused mainly by the evenness component.

The spatfall of Hydrobia ulvae, which occurred before sampling in June, changed the dominance pattern at Station 1 and thus is responsible for the low evenness value of 0.45 . The following high mortality of the mud snail reversed this change increasing the evenness again. A similar effect was caused by the spatfall of Abra alba in August at Station 2: the rise of dominance of this bivalve decreased the evenness from 0.75 to 0.68 . Presumably, later a high initial mortality of young bottom stages causes the same trend of increasing evenness (see also Rachor, 1977). 


\section{CONCLUSIONS}

Species composition and quantitative ranking reveal that the investigation area was situated in the transition zone between the classical Macoma baltica and Abra alba communities. Stations 1 and 3 can be regarded as belonging to the former, Station 2 to the latter biocoenosis. This observation corresponds with the results of Stripp (1969), Schulz (1969) and Arntz (1971), who also found the border zone between the two most important communities of the North and Baltic Seas at a depth of about $15 \mathrm{~m}$.

The analysis given above shows that strong small-scale local and short-term changes occur not only in shallow inshore areas with terrestial influences, estuaries, and other scarcely predictable environments, but also in apparently homogenous and constant soft-bottom communities. Production calculations based exclusively upon grab samples thus can lead to erroneous results if the net of stations is too wide or the period between sampling cruises is too long. In-situ investigations using saturation diving techniques, if applied more widely, promise the best opportunities for the necessary supplementation of results obtained by means of conventional methods.

Acknoweledgements. We are obliged to the company GKSS, Geesthacht (FRG), for working space in the UWL, and to the technical UWL-team for its support and cooperation. Our thanks are also due to Prof. Dr. W. Noodt for supporting the diver group at the Zoological Institute of the University Kiel, to Professor Dr. E. Walger and his assistant, Mrs. Faber, for carrying out the sediment analyses, and to Dr. J. Markham for correcting the manuscript.

\section{LITERATURE CITED}

Anger, K. \& Valentin, C., 1976. In-situ studies on the diurnal activity pattern of Diastylis ratbkei (Cumacea, Crustacea) and its importance for the "hyperbenthos". Helgoländer wiss. Meeresunters. 28, 138-144.

- Rogal, U., Schriever, G. \& Valentin, C., 1977. In-situ investigations on the echinoderm Asterias rubens as a predator of soft-bottom communities in the western Baltic Sea. Helgoländer wiss. Meeresunters. 29, 439-459.

Arntz, W. E., 1971. Biomasse und Produktion des Makrobenthos in den tieferen Teilen der Kieler Bucht im Jahr 1968. Kieler Meeresforsch. 27, 36-72.

- 1974. Die Nahrung juveniler Dorsche (Gadus morrbua L.) in der Kieler Bucht. Ber. dt. wiss. Kommn Meeresforsch. 23, 97-120.

- \& Brunswig, D., 1975. An approach to estimating the production of macrobenthos and demersal fish in a Western Baltic Abra alba community. Merentutkimuslait. Julk. 239, 195-205.

Bergh, G., 1974. Production of Macoma baltica (L.) (Lamellibranchiata) and notes on other ecologically important animals in Tvären Bay in the Baltic. Zoon 2, 143-152.

Beukema, J. J. \& Bruin, W. de, 1977. Seasonal changes in dry weight and chemical composition of the soft parts of the tellinid bevalve Macoma baltica in the Dutch wadden sea. Neth. J. Sea Res. 11, 42-55.

Blake, J. A., 1969. Reproduction and larval development of Polydora from Northern New England (Polychaeta: Spionidae). Ophelia 7, 1-63.

Dittmer, J. D., 1977. Zur Dynamik der kleinräumigen Verteilung von Polychaeten (Annelida) auf Sandböden im Sublitoral der Deutschen Bucht. Dipl.-Arb., Univ. Kiel, 71 pp.

Fish, J. D. \& Fish, S., 1974. The breeding cycle and growth of Hydrobia ulvae in the Dovey estuary. J. mar. biol. Ass. U.K. 54, 685-697. 
Gilbert, M. A., 1973. Growth rate, longevity and maximum size of Macoma baltica (L.). Biol. Bull. mar. biol. Lab., Woods Hole 145, 119-126.

Green, R. H., 1973. Growth and mortality in an artic intertidal population of Macoma baltica (Pelecypoda, Tellinidae). J. Fish. Res. Bd Can. 30, 1345-1348.

Jaccard, P., 1908. Nouvelles recherches sur la distribution florale. Bull. Soc. vaud. Sci. nat. 44, 223-270.

- 1912. The distribution of the flora in the alpine zone. New Phytol. 11, 37-50.

Kühlmorgen-Hille, G., 1963. Quantitative Untersuchungen der Bodenfauna in der Kieler Bucht und ihre jahreszeitlichen Veränderungen. Kieler Meeresforsch. 19, 42-66.

- 1965. Qualitative und quantitative Veränderungen der Bodenfauna der Kieler Bucht in den Jahren 1953-1965. Kieler Meeresforsch. 21, 167-191.

Pielou, E. C., 1966. Species-diversity and pattern-diversity in the study of ecological succession. J. theor. Biol. 10, 370-383.

- 1966. Shannon's formula as a measure of specific diversity: its use and misuse. Am. Nat. 100 (914), 463-465.

- 1969. An introduction to mathematical ecology. Wiley-Interscience, New York, 286 pp.

Rachor, E., 1971. Faunenverarmung in einem Schlickgebiet in der Nähe Helgolands. Helgoländer wiss. Meeresunters. 30, 633-651.

Rasmussen, E., 1973. Systematics and ecology of the Isefjord marine fauna (Denmark). Ophelia 11, 1-507.

Rogal, U., 1977. Merkmale des Ostseebenthos im Einflußbereich des Großen Belt. Dipl.-Arb., Univ. Kiel, 140 pp.

Sanders, H. I., 1960. Benthic studies in Buzzards Bay. III. The structure of the soft-bottom community. Limnol. Oceanogr. 5, 138-152.

Schulz, S., 1969. Das Makrobenthos der südlichen Beltsee (Mecklenburger Bucht und angrenzende Seegebiete). Beitr. Meeresk. 26, 21-46.

- 1969. Benthos und Sediment in der Mechlenburger Bucht. Beitr. Meeresk. 24-25, 15-55.

Segerstråle, S. G., 1960. Investigations on Baltic populations of the bivalve Macoma baltica (L.). I. Introduction. Studies on recruitment and its relation to depth in Finnish coastal waters during the period 1922-1959. Age and growth. Commentat. biol. 23, 1-72.

Stripp, K., 1969. Jahreszeitliche Fluktuationen von Makrofauna und Meiofauna in der Helgoländer Bucht. Veröff. Inst. Meeresforsch. Bremerhaven 12, 65-94.

Valentin, C. \& Anger, K., 1977. In-situ studies on the life cycle of Diastylis ratbkei (Cumacea: Crustacea). Mar. Biol. 39, 71-76.

Warwick, R. M. \& Price, R., 1975. Macrofauna production in an estuarine mud-flat. J. mar. biol. Ass. U.K. 55, 1-18.

Whittaker, R. H., 1967. Gradient analysis of vegetation. Biol. Rev. 42, 207-264.

Wilde, P. A. W. J. de, 1975. Influence of temperature on behaviour, energy metabolism, and growth of Macoma baltica (L.). In: 9th European Marine Biology Symposium. Ed. by H. Barnes. Univ. Press, Aberdeen, 239-256. 